\title{
PENDAMPINGAN DARING SUPERVISI AKADEMIK KEPALA MADRASAH DI MASA PANDEMI COVID-19
}

\author{
Eni Rindarti \\ Pengawas Madrasah Jakarta, Indonesia \\ E-mail: rindartieni@gmail.com
}

\begin{abstract}
This action research aims to improve the academic supervision competency of madrasa principals through technical guidance during the Covid-19 pandemic. The research was carried out in January s.d. May 2021. The Action Research involved four heads of Madrasah Aliyah in Central Jakarta as participants, researchers as mentors, and three observers. Research data were collected through observation, interviews, tests, filling out questionnaires, and document assessment. The research data were analyzed through data reduction, data presentation, and verification, accompanied by a description of quantitative data on test results, process assessment, and document assessment. Actions are carried out in two cycles. The results of observations showed an increase in online mentoring participation from $75 \%$ in the first cycle to $87.5 \%$ in the second cycle; there was an increase in the ability of madrasah principals in preparing academic supervision from $72 \%$ in the first cycle to $92.5 \%$ in the second cycle; the increase in knowledge about academic supervision increased from 73.25 before the action to 83 after the action, and improvement in the ability of the head of madrasah to prepare reports on academic supervision reached a score of $92.5 \% \%$ at the end of the activity. Based on this research, it can be concluded that online technical guidance during the Covid-19 pandemic can improve the ability of madrasa principals to carry out academic supervision.
\end{abstract}

Keywords: academic supervision, technical guidance, online.

\begin{abstract}
Abstrak
Penelitian Tindakan ini bertujuan meningkatkan kemampuan kepala madrasah melaksanakan supervisi akademik pada masa pandemi Covid-19 melalui pendampingan daring. Penelitian dilaksanakan pada bulan Januari s.d. Mei 2021. Penelitian Tindakan melibatkan empat kepala Madrasah Aliyah di Kota Jakarta Pusat sebagai peserta pendampingan, peneliti sebagai pendamping, dan tiga observer. Data penelitian dikumpulkan melalui observasi, wawancara, tes, pengisian kuesioner, serta penilaian dokumen. Data penelitian dianalisis melalui reduksi data, penyajian data, dan verifikasi, dilengkapi deskripsi data kuantitatif hasil tes, penilaian proses, dan penilaian dokumen. Tindakan dalam bentuk pendampingan daring dilaksanakan dalam dua siklus. Hasil observasi menunjukkan peningkatan pertisipasi pendampingan daring dari $75 \%$ pada siklus-I menjadi $87,5 \%$ pada siklus-II; terjadi peningkatan kemampuan kepala madrasah dalam menyusun program supervisi akademik dari $72 \%$ pada siklus-I menjadi 92,5\% pada siklus-II; kemampuan kepala madrasah menyusun laporan supervisi akademik mencapai skor 92,5\% \% di akhir kegiatan, dan peningkatan pengetahuan tentang supervisi akademik meningkat dari 73,25 sebelum tindakan menjadi 83 setelah tindakan. Berdasarkan penelitian ini dapat disimpulkan bahwa pendampingan daring pada masa pandemi Covid-19 dapa meningkatkan kemampuan kepala madrasah dalam melaksanakan supervisi akademik.
\end{abstract}

Kata kunci: supervisi akademik, pendampingan, daring. 


\section{PENDAHULUAN}

Pandemi Covid-19 telah membawa perubahan luar biasa dalam pendidikan. Aktivitas pembelajaran yang sebelumnya berlangsung melalui tatap muka di ruang kelas, berubah menjadi pembelajaran jarak jauh (PJJ) dalam jaringan (daring) berbasis teknologi digital (online). Tidak hanya itu, hampir semua aktivitas pendukung proses pendidikan dilakukan secara online seperti penerimaan peserta didik baru, rapat guru, pertemuan orang tua siswa, bimbingan/ konseling, termasuk supervisi pendidikan. Hal ini dinilai sebagai tindakan terbaik untuk menjaga kelangsungan pendidikan masa pandemi, namun bukan berarti tidak menimbulkan persoalan baru.

Pelaksanaan PJJ pada masa pandemi telah memunculkan persoalan antara lain keterbatasan fasilitas, rendahnya literasi oleh guru atau siswa, serta akses jaringan yang belum optimal. Akibat dari kondisi darurat, transformasi pembelajaran tatap muka menuju PJJ online berlangsung secara tiba-tiba, dilaksanakan tanpa persiapan yang matang. Dengan keterbatasannya, para pelaku pendidikan (peserta didik, guru, tenaga kependidikan) dituntut beradaptasi dengan kebiasaan baru. Dalam prakteknya, tidak sedikit guru mengalami kesulitan merencanakan, melaksanakan, serta mengevaluasi pembelajaran. Siswa juga mengalami kesulitan mengikuti pembelajaran karena minimnya interaksi dengan guru ataupun antar siswa.
Menyikapi kondisi tersebut di atas, kepala sekolah/madrasah berkewajiban melakukan supervisi akademik agar PJJ online berjalan sesuai harapan. Supervisi akademik dilakukan untuk membantu guru belajar, bagaimana meningkatkan kapasitas profesionalnya dalam mencapai tujuan pembelajaran (Zepeda, S. J., \& Mayers, 2014). Selain mengarahkan pelaksanaan tugas guru, supervisi akademik dilakukan untuk tindakan perbaikan jika ditemukan kekurangan dalam proses pembelajaran.

Dalam kondisi keterbatasan masa pandemi, kegiatan supervisi akademik harus ditingkatkan. Namun yang terjadi di lapangan justru sebaliknya. Selama PJJ online berlangsung, supervisi akademik jarang dilakukan. Hasil observasi awal pada semester-2 tahun pembelajaran 2019/ 2020 hingga terjadinya Pandemi Covid-19, seluruh kepala Masrasah Aliyah binaan di wilayah Jakarta Pusat belum melakukan supervisi akademik. Hal ini terjadi karena keterbatasan pemahaman terhadap proses dan teknis supervisi akademik yang tepat terjadap PJJ online. Mereka juga mengalami kesulitan merencanakan, melaksanakan, menindaklanjuti supervisi akademik.

Berangkat dari kondisi tersebut di atas, diperlukan intervensi tindakan untuk meningkatkan kemampuan supervisi akademik kepala madrasah. Merujuk pada Permen-PANRB No. 21/2010 pihak yang bertanggungjawab melakukan tindakan tersebut adalah 
Pengawas Madrasah melalui kegiatan pengawasan akademik dan pengawasan manajerial. Pengawasan manajerial diarahkan untuk meningkatkan kemampuan kepala madrasah sebagai supervisor bagi guru. Pengawasan akademik terkait materi serta program supervisi yang nantinya akan dilakukan kepala madrasah dalam meningkatkan kualitas pembelajaran.

Dalam prakteknya, banyak metode atau teknik yang dapat diterapkan oleh pengawas madrasah untuk meningkatkan kemampuan supervisi akademik kepala madrasah. Beberapa diantaranya cukup populer dan banyak diterapkan seperti training/pelatihan, coaching, mentoring, dan counseling (Engelbrecht, 2014; Niku, E. M., Maisyaroh, \& Hadi, 2020; Gallacher, 2020; Brockbank, A., \& McGill, 2012). Walapun beberapa metode tersebut dimaknai dalam terminologi yang sering dipertukarkan bahkan membingungkan, namun tetap memerlukan proses, metode, dan teknik yang hampir serupa dengan sedikit variasi yang disesuaikan dengan kebutuhan.

Peningkatan kemampuan supervisi akademik kepala madrasah pada masa pendemi dipandang sebagai kebutuhan saat ini, namun tetap berorientasi jangka panjang. Sementara itu, fakta di lapangan hampir semua Kepala Madrasah Aliyah Binaan tidak melaksanakannya dengan alasan keterbatasan kemampuan. Banyak aspek teknis yang belum dipahami dan perlu mendapat bantuan dari yang lebih berpengalaman. Prosesnya tidak sekedar transfer pengetahuan/keterampilan tetapi juga memberikan bantuan langsung dalam pelaksanaan tugas. Atas dasar itu, dipilih "pendampingan atau mentoring" sebagai format pembinaan untuk meningkatkan kemampuan kepala madrasah dalam melaksakaan supervisi akademik.

Pembinaan/mentoring mengacu pada hubungan fungsional di mana seseorang yang diposisikan memiliki kemampuan dan lebih berpengalaman memberikan bimbingan, bantuan, dukungan, dan saran untuk memfasilitasi pembelajaran atau pengembangan bagi orang lain yang diposisikan kurang atau berpengalaman (Smith \& Lynch, 2014; Astarini, 2016). Berbeda dengan pelatihan, pendampingan mencakup keseluruhan hubungan dengan pekerjaan dan kemampuan berkembang, lebih dari sekedar transmisi pengetahuan/ keterampilan yang terbatas (Smith, R., \& Lynch, 2014). Pendampingan memiliki perbedaan dengan coaching yang lebih terfokus pada perbaikan kinerja serta penyelesaian masalah dalam pekerjaan (Smith, R., \& Lynch, 2014; Parsloe, E., \& Leedham, 2017). Berbeda juga dengan konseling yang diberikan dalam bentuk bimbingan dan nasihat dan dilaksanakan jangka waktu yang relatif lama (Smith, R., \& Lynch, 2014). Atas dasar itu, pendampingan/mentoring 
merupakan teknik potensial diterapkan dalam upaya meningkatkan kemampuan supervisi akademik kepala madrasah.

Pendampingan merupakan program dimana seseorang berbagi pengetahuan dan pengalaman kepada orang lain yang membutuhkan, secara dinamis dapat mempengaruhi perkembangan profesional untuk pembelajaran di sekolah/lembaga pendidikan (Kutsyuruba, B., Godden, L., \& Walker, 2020). Melalui praktik pemberian bantuan dan bimbingan, pendampingan memiliki pengaruh positif terhadap peningkatkan pengetahuan, serta efektif mendukung pengembangan profesional (Nopriyeni et al., 2019). Ismail, Abdullah, \& Francis (2009) menjelaskan bahwa pendampingan adalah metode pengembangan SDM yang cukup efektif dan penting diterapkan dalam organisasi karena berpotensi mendorong pesertanya berkembang secara profesional. Selain meningkatkan kinerja pesertanya, manfaat penting pendampingan dapat mendorong peningkatan kemampuan belajar dan pengetahuan metakognisi (Kadir, 2021). Uraian di atas menjelaskan bahwa pendampingan cukup potensial diterapkan oleh pengawas madrasah dalam upaya meningkatkan kemampuan supervisi akademik kepala madrasah.

Seiring adaptasi kebiasaan baru, kegiatan pengawasan tatap muka berubah menjadi pengawasan daring.
Pengawas tidak lagi melakukan kunjungan fisik ke madrasah binaan tapi dikemas dalam kunjungan virtual. Ketika pendampingan dipilih sebagai teknik pengawasan, maka pendampingan harus dilaksanakan secara daring. Keuntungan utama pendampingan daring adalah aktivitas yang lebih berpusat pada peserta daripada pendampingan tradisional (Walsh, 2016). Di samping itu, pendampingan dapat diatur pada waktu yang sesuai, tidak harus dalam jadwal khusus yang dibatasi kesibukan tugas.

Aspek penting lain pendampingan daring adalah untuk mendukung aktivitas pembinaan yang terpisah secara geografis (Dorner et al., 2021). Dalam situasi pandemi, pendampingan daring dibutuhkan kaitannya dengan phisycal dan social distancing. Melalui pendampingan daring, peserta dan pendamping bekerja menggunakan media online, membuat proses pendampingan tersebut menjadi istimewa (Baumann \& Schachtner, 2020), tanpa dibatasi oleh ruang dan waktu. Pendampingan daring diterapkan sebagai sebuah metode kerja menggunakan proses yang berlangsung synchronous dan asynchronous sebagai nilai tambah untuk mencapai tujuan. Kehadiran platform media sosial telah membuka jalan bagi pengawas madrasah untuk mengubah strategi pelaksanaan pengawasan. Dengan kata lain, pendampingan daring dapat dijadikan sebagai media komunikasi 
dalam konteks pelaksanaan pembinaan kepala madrasah dan guru.

Keterbatasan kemampuan kepala madrasah dalam supervisi akademik dapat diatasi melalui tindakan pengawasan oleh pengawas madrasah. Salah satu metode/ teknik yang potensial diterapkan adalah pendampingan. Dalam situasi pandemi Covid-19 proses pendampingan dapat dilaksanakan secara daring (online).

Berdasarkan latar belakang yang diuraikan sebelumnya, rumusan masalah yang dikaji melalui penelitian ini adalah: "Bagaimana meningkatkan kemampuan supervisi akademik kepala madrasah madrasah pada masa Pandemi Covid-19 melalui pendampingan daring oleh pengawas madrasah di MA binaan Kota Jakarta Pusat?"

Penelitian ini dilaksanakan dengan tujuan untuk meningkatkan kemampuan kepala madrasah melaksanakan supervisi akademik pada masa Pandemi Covid-19 melalui pendampingan daring oleh pengawas madrasah di MA binaan, Kota Jakarta Pusat. Melalui penelitian ini akan dijelaskan proses pendampingan daring serta peningkatan kemampuan supervisi akademik kepala madrasah pada masa pandemi Covid-19 setelah mengikuti pendampingan tersebut.

Hasil penelitian ini diharapkan dapat memberikan manfaat dengan diperolehnya pemahaman dan pengalaman baru tentang pendampingan daring yang dalam upaya meningkatkan kemampuan supervisi akademik kepala madrah pada masa pandemi Covid-19. Bagi kepala madrasah, hasil penelitian diharapkan memberikan manfaat secara langsung terkait dengan pelaksanaan tugas sebagai supervisor bagi guru, sehingga memberikan perbaikan terhadap proses pembelajaran daring yang dilaksanakan di madrasah. Diharapkan teknik pendampingan daring yang telah diterapkan dalam penelitian ini dapat dijadikan sebagai rujukan, alternatif metode pengawasan untuk meningkatkan kemampuan dan kinerja kepala madrasah dan juga guru di madrasah khususnya pada masa Pandemi Covid-19 atau selama aktivitas pembelajaran jarak jauh (PJJ) berlangsung.

\section{METODE}

Penelitian ini dilaksanakan dengan menggunakan metode penelitian tindakan (action research). Pelaksanaan kegiatan pendampingan ditetapkan sebagai variabel tindakan. Kemampuan supervisi akademik kepala madrasah ditetapkan sebagai variabel tujuan. Penelitian dilakukan secara kolaboratif melibatkan empat orang kepala Madrasah Aliyah Binaan di Kota Jakarta Pusat yaitu MAS Al Mudatsiriyah, MAS Jakarta Pusat, MAS Istiqlal dan MAS Jamiat Kheir. Kepala madrasah ditetapkan sebagai subyek penelitian yang berperan sebagai peserta pendampingan. Pengawas 
madrasah (peneliti) berperan sebagai sebagai pendamping yang melaksanakan tindakan. Penelitian ini melibatkan tiga observer yaitu rekan sejawat, wakil kepala madrasah, dan perwakilan guru senior salah satu madrasah. Kegiatan penelitian berlangsung lima bulan, dimulai bulan Januari 2021 s.d. Mei 2021.

Tindakan pendampingan dalam penelitian ini dilaksanakan dalam dua siklus. Setiap siklus terdiri dari rangkaian kegiatan yaitu perencanaan, pelaksanaan, pengamatan, dan refleksi. Implementasi tindakan Siklus-I dilaksanakan dalam tiga pertemuan. Pertemuan-1 menggunakan aplikasi WA-group; pertemuan-2 melalui tatap muka online menggunakan aplikasi Zoom secara synchronous; pertemuan-3 dilakukan menggunakan aplikasi WAgroup. Materi pendampingan pada siklus I meliputi: merencanakan supervisi akademik oleh kepala; supervisi akademik dalam aspek perencanaan pembelajaran; serta evaluasi supervisi akademik dalam aspek perencanaan pembelajaran.

Implementasi tindakan pada siklus-II dilaksanakan melalui tiga pertemuan. Pertemuan pertama melalui tatap muka on-line menggunakan aplikasi Zoom secara synchronous; pertemuan kedua dilakukan dalam bentuk pendampingan individual melalui aplikasi WA; pertemuan ketiga melalui tatap muka online menggunakan aplikasi Zoom secara synchronous. Materi pendampingan siklus II meliputi: supervisi akademik dalam aspek pelaksanaan pembelajaran, supervisi akademik dalam aspek penilaian pembelajaran, \& evaluasi keterlaksanaan supervisi akademik oleh kepala madrasah.

Data dalam penelitian dikumpulkan melalui kegiatan tes tertulis, pengamatan/ observasi, pengisian kuesioner, wawancara terstruktur, serta analisis dan penilaian dokumen. Data kualitatif tentang proses pendampingan yang diperoleh melalui observasi dan wawancara dianalisis melalui reduksi data, penyajian data, penarikan kesimpulan dan verifikasi. Data kuantitatif tentang proses pendampingan yang diperoleh melalui kuesioner sarta kemampuan supervisi akademik yang diperoleh melalui tes tertulis dan penilaian dokumen dianalisis menggunakan statistik deskriptif, dilanjutkan dengan analisis komparatif untuk menguji keberhasilan implementasi tindakan yang dilaksanakan. Implementasi tindakan dalam penelitin ini dikatakan berhasil jika memenuhi indikator berdasarkan kriteria: (1) skor hasil penilaian aktivitas proses peserta dalam mengikuti kegiatan $\geq 76 \%$; (2) skor hasil tes dan penilaian dokumen yang dibuat masing-masing peserta $\geq 76 \%$.

\section{HASIL DAN PEMBAHASAN}

Supervisi akademik yang dilakukan kepala madrasah terhadap guru bagian integral tugas pengelolaaan pendidikan. Supervisi akademik 
dilakukan dengan tujuan meningkatkan kualitas pendidikan di madrasah secara berkelanjutan. Untuk mendukung pelaksanaan tugas tersebut, kepala madrasah harus menguasai tiga sub kompetensi supervisi akademik yaitu merencanakan, melaksanakan, menindak-lanjuti supervisi akademik dalam rangka meningkatkan profesionalisme guru.

Untuk mengetahui kemampuan awal kepala madrasah (peserta pendampingan), dilakukan tes tertulis sebelum kegiatan pendampingan dilaksanakan. Hasil tes tersebut memperlihatkan capaian skor rata-rata 73,25 . Hal ini menunjukkan bahwa kemampuan supervisi akademik kepala madrasah pada masa Pandemi di MA Binaan di Kota Jakarta Pusat perlu ditingkatkan. Tahap selanjutnya dilakukan tindakan melalui pendampingan daring.

\section{Implementasi \& Hasil Tindakan Siklus-I}

Pendampingan

siklus-I difokuskan pada peningkatan kemampuan peserta dalam merencanakan supervisi akademik, kemudian dilanjutkan dengan kegiatan supervisi akademik aspek perencanaan pembelajaran termasuk evaluasi supervisi dalam aspek tersebut. Pertemuan pertama dan kedua dilakukan dalam bentuk pendampingan kelompok menggunakan WA-group dan Zoommeeting, dilanjutkan dengan pendampingan secara individual melalui aplikasi WA.

Berdasarkan data jawaban kuesioner yang diisi oleh peserta, pendampingan siklus-I mendapat penilaian dengan skor rata-rata $75 \%$, termasuk kategori "baik", namun belum memenuhi kriteria kinerja tindakan (>76\%). Dari empat aspek yang dinilai, dua diantaranya mendapat skor $70 \%$ yaitu semangat dan antusias untuk mengikuti tahapan kegiatan. Merujuk pada hasil wawancara, kelemahan dari kedua aspek tersebut diakibatkan oleh persoalan teknis terkait kebiasaan dalam pembinaan yang sebelumnya dilakukan melalui tatap muka secara langsung. Sedangkan dua aspek lainnya mendapat skor $80 \%$ yaitu aspek ketertarikan \& kebutuhan terhadap materi pendampingan. Peserta umumnya memiliki persepsi yang sama tentang pentingnya supevisi akademik, namun pelaksanaannya selama PJJ terkendala oleh masalah metode dan teknik supervisi yang sesuai untuk diterapkan.

Berdasarkan hasil observasi siklus-I, ditemukan masalah terkait kedisiplinan dalam mengikuti tahapan pendampingan kelompok terutama pada pertemuan-1 dan pertemuan-2 yang dilaksanakan secara kelompok dan terjadwal. Tidak semua peserta dapat hadir dalam pertemuan kelompok, diantaranya ada peserta yang diwakilkan. Di samping itu, ditemukan kendala teknis terkait akses internet dan jaringan untuk dapat 
bergabung melalui aplikasi Zoommeeting di pertemuan kedua. Akibatnya, penyajian materi pertemuan-2 kurang optimal.

Kendala-kendala yang terjadi pada pertemuan -1 dan pertemuan-2 diantisipasi dalam pertemuan-3 yang dilaksanakan dalam format pendampingan individual. Dalam pertertemuan-3, pendamping dan peserta dapat berinteraksi secara langsung menggunakan aplikasi WA dalam rentang waktu ditetapkan namun tidak dijadwal secara khusus. Dibandingkan dengan dua pertemuan sebelumnya, penyajian materi dalam pertemuan-3 menjadi lebih optimal. Antusias dan semangat peserta mengikuti pertemuan individul relatif lebih tinggi jika dibandingkan dengan pendampingan yang dilakukan dalam kelompok.

Terkait dengan ketercapaian tujuan pendampingan pada siklus-I diperoleh hasil sebagai berikut: (1) Pada awalnya, pemahaman peserta tentang mekanisme, metode, dan sasaran supervisi akademik pada masa pandemi masih beragam;

Pembahasan materi pada pertemuan-1 dan pertemuan-2 cenderung terfokus pada kendala pelaksanaan PJJ, melalui dinamika pendampingan akhirnya kendala tersebut disepakati sebagai sasaran supervisi; (3) Pasca pertemuan2 , secara bertahap setiap peserta mulai memiliki pemahaman yang sama ketika ditugaskan menuangkannya dalam program supervisi akademik; serta (4)
Kesulitan umum yang dihadapi peserta melaksanakan supervisi akademik pada masa pendemi adalah dalam komponen penyusunan instrumen supervisi.

Hasil penilaian dokumen program supervisi yang disusun setelah pertemuan-2 menunjukkan kemampuan peserta baru mencapai $72,5 \%$, termasuk kategori cukup, belum memenuhi kriteria kinerja tindakan $(>76 \%)$. Dari empat aspek yang dinilai dua diantaranya mendapat skor yang rendah yaitu penjadwalan kegiatan (63\%) dan instrumen supervisi (50\%). Kedua aspek tersebut selanjutnya lebih diperkuat pada pertemuan-3 melalui pendampingan individual. Dua aspek lainya, kelengkapan dokumen (dasar hukum, penugasan tim) termasuk kategori baik dengan skor $>76 \%$. Pada tahap selanjutnya, peserta ditugaskan melakukan penyempurnaan, melengkapi dokumen, termasuk menambahkan jenis-jenis kegiatan sesuai materi yang disajikan pada pertemuan-1, siklus-II.

Berdasarkan hasil observasi, catatan lapangan, dan wawancara yang dilakukan dengan para peserta pendampingan, dapat dikemukakan langkah-langkah perbaikan proses pendampingan selanjutnya yaitu sebagai berikut: (1) pembahasan materi lebih difokuskan pada pemecahan masalah yang dihadapi oleh setiap peserta; (2) peningkatan intensitas pendampingan individual dengan memberikan akses serta kesempatan yang lebih luas pada peserta untuk 
mengajukan pertanyaan tentang materi pendampingan, termasuk hal-hal teknis yang harus disesuaikan dengan kondisi madrasahnya; serta (3) penyajian materi dilengkapi modul (bahan ajar) atau juknis terkait pelaksanaan supervisi akademik pada masa pandemi. Langkah-langkah tersebut diterapkan pada pelaksanaan pendampingan siklus-II.

\section{Implementasi \& Hasil Tindakan}

\section{Siklus-II}

Pendampingan

siklus-II

difokuskan pada peningkatan kemampuan supervisi akademik dalam aspek pelaksanaan dan penilaian pembelajaran serta evaluasi keterlaknsanaan supervisi. Target nyata yang ingin dicapai melalui pendampingan siklus-II adalah terlaksananya supervisi akademik oleh setiap peserta. Hasil dari kegiatan tersebut dituangkan dalam perencanaan program serta laporan supervisi akademik yang telah dilakukan peserta di tempat kerja masing-masing.

Pendampingan siklus-II dilakukan melalui tiga pertemuan. Pertemuan-1 dalam bentuk pendampingan kelompok menggunakan aplikasi Zoom. Melalui pertemuan ini, pendamping menyajikan materi lebih difokuskan pada aspek-aspek teknis pelaksanaan supervisi akademik meliputi tahapan proses, instrumen dan cara menggunakannya, termasuk contoh pengisian instrumen. Di akhir $\begin{array}{llr}\text { pertemuan, } & \text { peserta } & \text { diminta } \\ \text { menuntaskan } & \text { penyusunan } & \text { serta }\end{array}$ penyempurnaan program supervisi yang telah dibuat sebelumnya, serta melengkapinya dengan instrumen sesuai materi yang disajikan pada pertemuan-1 siklus-II. Dokumen program tersebut selanjutnya diserahkan pada pendamping untuk mendapatkan penilaian sebelum pertemuan-2 dilaksanakan.

Pertemuan-2 (siklus-II) dilakukan dalam bentuk pendampingan individual. Pada pertemuan ini, peserta didampingi untuk melakukan praktik supervisi secara langsung di madrasahnya masing-masing. Kegiatan praktik yang dilakukan berpedoman pada program perencanaan yang telah dibuat sebelumnya. Dalam kurun waktu pertemuan-2 berlangsung, peserta diberi kesempatan seluasluasnya untuk bertanya termasuk meminta arahan kepada pendamping tentang kegiatan supervisi akademik yang dilaksanakannya. Walaupun memakan waktu yang relatif lama, peserta lebih antusias mengikuti kegiatan dibandingkan siklus-I.

Pertemuan-3 (siklus-II) dilakukan melalui pendampingan kelompok. Pada pertemuan ini, peserta didampingi untuk melakukan praktik penyusunan laporan supervisi akdemik yang dilakukan pada pertemuan-2. Peserta mendapatkan arahan pendamping tentang prosedur evaluasi pelaksanaan supervisi serta menuangkan hasilnya dalam sebuah laporan supervisi 
Wawasan:

Jurnal Kediklatan Balai Diklat Keagamaan Jakarta PISSN: 2548-9232; EISSN: 2775-3573

Volume 2 Nomor 2 Tahun 2021: 121-133

akademik. Selain itu, dibahas tindak lanjut supervisi akademik yang telah dilakukan setiap peserta. Inti dari tindak lanjut yang dimaksud adalah tindakan perbaikan yang harus dilakukan oleh kepala madrasah dan guru atas kekurangan/kelemahan yang ditemukan pada saat supervisi akademik dilaksanakan. Pada tahap selanjutnya, peserta ditugaskan menuntaskan laporan tersebut serta menyerahkannya untuk mendapatkan penilaian. Sebelum kegiatan pendampingan diakhiri, dilakukan tes tertulis untuk mengukur keberhasilan tindakan yang telah dilakukan.

Secara

keseluruhan, pendampingan siklus-II lebih baik dibandingkan dengan siklus-I (sebelumnya). Berdasarkan data jawaban kuesioner, pendampingan siklus-I mendapat penilaian dengan skor rata-rata 87,5\%, kategori "sangat baik", memenuhi kriteria kinerja tindakan (>76\%). Terdapat peningkatan kualitas proses dibandingkan pendampingan siklus-I pada Gambar 1. Dari keempat aspek yang dinilai, semuanya mendapat skor $>76 \%$.

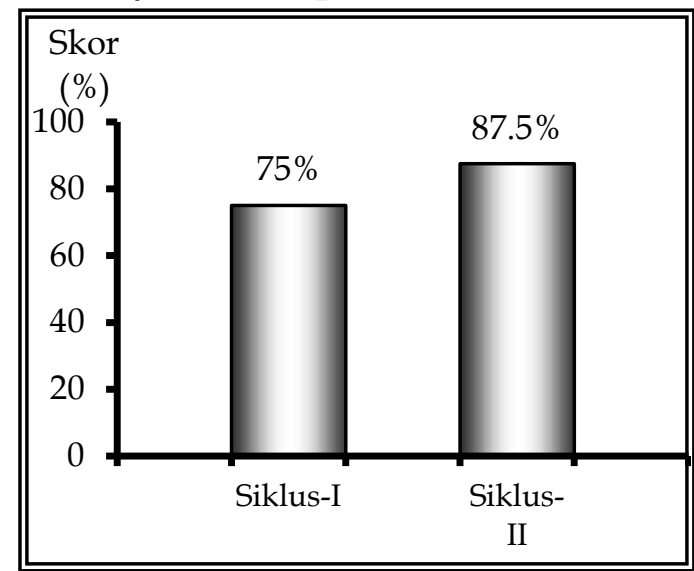

Gambar 1 Peningkatan Proses Pendampingan
Berdasarkan observasi dan wawancara, peserta telah memiki persepsi yang sama tentang manfaat supervisi akademik. Hal ini mendorong kesungguhan peserta untuk mengikuti setiap tahapan kegiatan dengan lebih baik lagi.

Hasil penilaian dokumen program/ perencanaan supervisi akademik pada Tabel 1 memperlihatkan adanya peningkatan skor dibandingkan siklus sebelumnya.

Tabel 1 Hasil Penilaian Dokumen Program Supervisi Akademik

\begin{tabular}{clcc}
\hline \multirow{2}{*}{ No. } & \multirow{2}{*}{ Madrasah } & \multicolumn{2}{c}{ Skor } \\
\cline { 3 - 4 } & & Siklus-I & Siklus-II \\
\hline 1 & Al Mudatsiriyah & $75 \%$ & $95 \%$ \\
2 & Jakarta Pusat & $70 \%$ & $90 \%$ \\
3 & Istiqlal & $75 \%$ & $95 \%$ \\
4 & Jamiat Kheir & $70 \%$ & $90 \%$ \\
\hline & Rata-rata & $72,5 \%$ & $92.5 \%$ \\
\hline
\end{tabular}

Skor rata-rata penilaian dokumen program pada siklus-II sebesar 92,5\%, memenuhi kriteria kinerja tindakan $(>76 \%)$.

Peningkatan

kemampuan supervisi akademik dapat dilihat berdasarkan hasil tes tertulis sebelum tindakan (pretes) dan sesudah pendampingan (postes) pada Tabel 2.

Tabel 2 Hasil Tes Kemampuan Supervisi Akademik

\begin{tabular}{clcc}
\hline \multirow{2}{*}{ No. } & \multirow{2}{*}{ Madrasah } & \multicolumn{2}{c}{ Skor } \\
\cline { 3 - 4 } & & Pretes & Postes \\
\hline 1 & Al Mudatsiriyah & 75 & 86 \\
2 & Jakarta Pusat & 70 & 80 \\
3 & Istiqlal & 76 & 84 \\
4 & Jamiat Kheir & 72 & 82 \\
\hline & Rata-rata & 73,25 & 83,00 \\
\hline
\end{tabular}


Rata-rata skor pretes pada kondisi awal sebesar 73,25, meningkat menjadi 83,00 pada postes setelah peserta mengikuti pendampingan. Skor tersebut termasuk kategori baik, melampauai kriteria kinerja tindakan $(>76 \%)$.

Setelah semua tahapan kegiatan pendampingan dilaksanakan, termasuk praktik supervisi akademik oleh kepala madrasah di tempatnya masingmasing, peserta menyampaikan dokumen laporan hasil supervisi akademik. Hasil penilaian dokumen diperlihatkan pada Tabel 3.

Tabel 3 Hasil Penilaian Dokumen Laporan Supervisi Akademik

\begin{tabular}{clc}
\hline No. & \multicolumn{1}{c}{ Madrasah } & Skor \\
\hline 1 & Al Mudatsiriyah & $95 \%$ \\
2 & Jakarta Pusat & $90 \%$ \\
3 & Istiqlal & $95 \%$ \\
4 & Jamiat Kheir & $90 \%$ \\
\hline & Rata-rata & $92,5 \%$ \\
\hline
\end{tabular}

Rata-rata skor penilaian dokumen laporan supervisi sebesar 92,5\%, termasuk kategori "sangat baik", memenuhi kriteria kinerja tindakan $(>76 \%)$.

Hasil penelitian ini memperlihatkan bukti empiris bahwa pendampingan daring dapat diterapkan oleh pengawas madrasah untuk meningkatkan kemampuan kepala madrasah dalam melaksanakan supervisi akademik, khususnya pada masa pendemi Covid-19. Melalui pendampingan, terjalin hubungan fungsional, bimbingan, bantuan, dukungan, serta saran untuk memfasilitasi pembelajaran atau pengembangan (Smith, R., \& Lynch, 2014).

Relevan dengan penelitian Dorner (2021) dan Walsh (2016), pendampingan daring dalam penelitian ini diterapkan untuk mendukung proses pembinaan yang terpisah oleh pembatasan fisik dalam masa pandemi. Walaupun dilaksanakan secara online, hasilnya tetap dapat memberikan pengalaman kontekstual dan transformatif menuju pengembangan, bahkan membuat pendampingan menjadi lebih istimewa tanpa dibatasi ruang dan waktu (Baumann \& Schachtner, 2020). Terkait perpaduan teknik kelompok \& individual, penelitian ini mendukung studi Stoeger dkk. (2021) yang menjelaskan bahwa pendampingan terpadu menciptakan komunikasi yang lebih luas dibandingkan kelompok.

Penelitian ini telah menunjukkan pendampingan daring cukup efektif dalam meningkatkan kemampuan, pengetahuan, serta pelaksanaan tugas. Pendampingan memiliki pengaruh positif terhadap peningkatkan pengetahuan (Nopriyeni et al., 2019). Pendampingan adalah metode pengembangan SDM yang efektif mendorong pesertanya berkembang secara profesional (Ismail et al., 2009), serta mendorong peningkatan kemampuan belajar (Kadir, 2021). Kemampuan dan kierja dalam melaksanakan tugas dapat ditingkatkan melalui pendampingan. 


\section{KESIMPULAN}

Berdasarkan hasil penelitian yang dilakukan terhadap kepala Madrasah Aliyah binaan di Kota Jakarta Pusat, diperoleh kesimpulan sebagai berikut: $\underline{\text { Pertama, }}$ pendampingan daring dapat digunakan oleh pengawas madrasah untuk meningkatkan kemampuan supervisi akademik kepala madrasah pada masa pendemi Covid-19. Prosesnya dilakukan dengan menciptakan hubungan fungsional melalui bimbingan, bantuan, dukungan, dan saran untuk memfasilitasi kegiatan belajar pesertanya. Kedua, pendampingan daring dapat meningkatkan kemampuan supervisi akademik kepala madrasah dalam penyusunan program, pelaksanaan kegiatan, evaluasi pelaksanaan, penyusunan laporan, serta menentukan tindak lanjut supervisi akademik pada masa pandemi Covid19. Berdasarkan hasil penelitian ini, pengawas madrasah dapat menggunakan pendampingan daring sebagai alternatif tindakan dalam melakukan pengawasan, baik itu pengawasan akademik atau pengawasan manajerial. Dengan tujuan yang sama, kepala madrasah dapat menerapkan pendampingan daring dalam melakukan pembinaan kepada guru. Untuk penelitian selanjutnya perlu dikaji sejuah mana efektivitas pendampingan daring dalam meningkatkan kemampuan dan kinerja dalam bidang tugas dan sasaran yang berbeda, termasuk studi komparatif dengan metode atau teknik lain seperti coaching, training, atau counseling.

\section{DAFTAR PUSTAKA}

Baumann, N., \& Schachtner, C. (2020). Social Media as a channel for public sector transformation via online mentoring. Central and Eastern European EDem and EGov Days, 338, 217-229. https:/ / doi.org/10.24989/ocg.338.17

Brockbank, A., \& McGill, I. (2012). Facilitating Reflective Learning: Coaching, Mentoring and Supervision. Kogan Page.

Dorner, H., Misic, G., \& Rymarenko, M. (2021). Online mentoring for academic practice: strategies, implications, and innovations. Annals of the New York Academy of Sciences, 1483(1), 98-111. https://doi.org/10.1111/nyas.14301

Engelbrecht, L. (2014). COACHING, MENTORING AND CONSULTATION: THE SAME BUT DIFFERENT ACTIVITIES IN SUPERVISION OF SOCIAL WORKERS IN SOUTH AFRICA? Social Work/Maatskaplike Werk, 48(3). https:/ / doi.org/10.15270/48-3-90

Gallacher, K. (2020). Supervision, Mentoring: Methods for Supporting Personnel Development. The University of North Carolina. https://fpg.unc.edu/sites/fpg.unc.edu/files/resources/ReformingPersonnelPre p_08-191_214.pdf

Ismail, A., Abdullah, M. M., \& Francis, S. K. (2009). Mentoring program and its impact on individuals' advancement in the Malaysian context. Journal of Industrial 
Engineering and Management, 2(3). https://doi.org/10.3926/jiem.2009.v2n3.p592615

Kadir, A. (2021). THE EFFECTS OF COACHING AND MENTORING ON METACOGNITION KNOWLEDGE AMONG MALAY LANGUAGE TEACHERS IN SABAH, MALAYSIA. American International Journal of Education and Linguistics Research, 4(1), 18-30. https:// doi.org/10.46545/aijelr.v4i1.284

Kutsyuruba, B., Godden, L., \& Walker, K. (2020). The Effect of Contextual Factors on School Leaders' Involvement in Early-Career Teacher Mentoring: A Review of the International Research Literature. Research in Educational Administration $\mathcal{E}$ Leadership, 5(3). https://doi.org/10.30828/real/2020.3.3

Niku, E. M., Maisyaroh, \& Hadi, S. (2020). Developing Teacher Professionality Through Education Supervision. International Research-Based Education Journal, 2(2), 45-53.

Nopriyeni, N., Prasetyo, Z. K., \& Djukri, D. (2019). The Implementation of Mentoring Based Learning to Improve Pedagogical Knowledge of Prospective Teachers. International Journal of Instruction, 12(3), 529-540. https://doi.org/10.29333/iji.2019.12332a

Parsloe, E., \& Leedham, M. (2017). Coaching and Mentoring: Practical Techniques for Developing Learning and Performance. Kogan Page.

Smith, R., \& Lynch, D. (2014). Coaching and Mentoring: A review of literature as it relates to teacher professional development. International Journal of Innovation, Creativity and Change, 1(4).

Walsh, K. (2016). Online mentoring in medical education. South African Family Practice, 58(sup1), S7-S8. https://doi.org/10.1080/20786190.2015.1059020

Zepeda, S. J., \& Mayers, R. S. (2014). Supervision Across the Content Areas. Routledge. 